\title{
The Impact of Conditional Determinants of Purchase Attitude of Store Brands in Food and Grocery in Indian Retailing-An Empirical Study in Twin Cities of Hyderabad
}

\author{
Tirthala Naga Sai Kumar ${ }^{1}$, Dr. M. Ravindar Reddy ${ }^{2}$, Kondapalli Mahathi ${ }^{3}$ \\ ${ }^{I}$ Research Scholar At School Of Management National Institute Of Technology Warangal India \\ ${ }^{2}$ Associate Professor, School Of Management, National Institute Of Technology Warangal India \\ ${ }^{3}$ MBA Student,University College For Women, Warangal, India
}

\begin{abstract}
The consumer psychology is a very complex phenomenon, which changes from time to time, and depends on fast changing applications of science \&technology and ever fascinating management skills. The present research paper highlights the key factors in retailing world that play an important role in influencing the perceptual processing of the buyers' black box in selecting the retail store and retail brands. The changes in the perceptions about store brands and retail store may influence the purchase attitude of shoppers. These variables are studied extensively in order to assess their role in changing the purchase behavior of the store brand consumers.The study focuses on what-if analysis exclusively in analyzing the black box phenomena.
\end{abstract}

Key words: consumer behavior, store brands, decision making, purchase interest, food and grocery.

\section{Introduction:}

Consumers are always right in their strategies to buy. The retailers however create a gap between the consumers and retailers themselves by discarding the relationship with the loyal customers, by an invisible wall of profits.The consumers may not appreciate the profits of retailers but hate their attitude in ignoring customers efforts to reach the store,by spending time,money and efforts with patience and silence.The customers' difficulties ,problems and suggestions need to addressed carefully. The exhausted sales people become numb and dumb after receiving the customers.Their response to the help asked by the shoppers is ,sometimes, uncheerful.The self search for items on the shelves seems to be awesome sometimes but irritating most of the times.

Customers expect anything on the basis of logic. So, the gap between the expectations and realization of expectations is simply a human error.The present study directly focuses on these issues, with an idea that buyers are conscious of what they are doing ,though sometimes they show impulsive buying behavior.The consumers expect quality,value,most importantly the minimization of cost,while purchasing what they want.It is $100 \%$ rational approach.However when they visit with children,loved ones they might be little emotional and traditional,too.The common man expects some kind of personal help from the retailers before purchase.If it is addressed properly he would not hesitate to spend extra money if necessary,while purchasing items. The retailers who are fascinated to sell store brands must understand the buyer's black box role in purchase process. The usual buyer's buying process includes a 5 stage model where he recognizes his problem,searches for information on solutions and alternatives,evaluates them with friends, experts, and dealers, and finally, purchases and experiences post purchase satisfaction or dissatisfaction. If the retailers understand the basic instincts of human nature then it is not a difficult task to convince their customers and convert them to store loyals. The retailers who ignore these factors will find their store with a few or none, most of the time.

The conventional store owners ran their shops or super markets generations after generations with human relations with their long loyal customers, but the recent surge of super market chains and malls have deprived them of profits by dragging their regular customers away from them. The modern retail formats no doubt attract their potential and local customers in a very large number,but at the same time they lose their customers,too.The main reason is that the retailers focus little on the psychology of the customers .Themodern outlets are decorated with astonishing designs,a very good ambience of the store,attractive multi-coloured lights,a decent back ground music and so on captivate the exhausted shoppers.However that's not the ends and means ,but the retailers must address their latent expectations otherwise the whole episode comes to a halt.Thus human psychology plays a powerful role in decision making process.

\section{The Objectives Of The Study:}

The present study which is part of the working paper has the following objectives .

1.To find out the factors that influence the loyalty and purchase intention of the store brands in food and grocery sector in retailing. 
2.To identify the factors that affect the retailers to prefer the store brands to the manufacturer brands in food and grocery.

3.To study the effect of the socio-economic and demographic attributes on store brand purchase intention and to suggest the curative measures and modality for better performance of private label brands in food and grocery sector.

II. Literature Review:

The past research on retailing business focused on value for money,quality,risk,promotions,convenience and price aspects. Ailawadi and Keller (2004) categorized these private labels under 4 tiers. They are( 1).Low quality and low priced generics without any labels on their packages;(2).Medium quality private labels;(3).Somewhat less expensive but comparable quality store brands;(4).Premium quality private labels that surpass the quality of national brands but are higher priced than the national brands.

Ailawadi and Keller caution the retailers to ,first, identify the target market and then adopt the appropriate categories of private labels so that ultimately the market coverage is substantial.Depending on the retailer's store strategy, the retailer adopts any one or combination of these 4 categories of store brands. The private label brands stand at the sixth position among the top 10 issues in the world ,as reported by Nielsen(Baltas and Argouslidis,2007).

The consumers usually estimate the brand quality on the basis of the judgment on direct factors like ingredients,taste, and texture whilst the indirect attributes like price ,brand name, advertisements,publicity and package,shelf place and ambience of store formats etc(Dick et al.,1997). Numerous studies have shown that the shoppers' propensity to regularly buy the store brands depends on a variety of different constructs, and more specifically, on a favorable attitude toward these reseller brands (Binninger, 2008; Dick, Jain and Richardson, 1996). The store brand prone shoppers are found to be less sensitive to national brands and advertising (Bellizi et al., 1981). the effect of consumer involvement in store brand purchase behavior was studied in the past and it was found that the greater involvement leads to better knowledge which in turn influences the store brand proneness positively(Miqueal,Cappliure and Manzano,2002).

The present study attempts to fill the gap between the perceptions of customers and expectations of the customers about the retailer brands by a careful observation and an analysis of the attitudes of the consumers regarding the concerned issues and challenges faced by the retailers in their strategy formulations.

\section{Methodology}

The present study is qualitative in nature and consists of two phases,i.e., the exploratory study and descriptive study.The various store managers and incharges were consulted for an in-depth study of the issues at various malls,in the twin cities of Hyderabad. The sample consists of 316 respondents from various parts of the select twin cities of Hyderabad metro .The structured questionnaire was given to 375 respondents out of which only 316 are found to be free from errors and accurate and the rest were found incomplete and hence discarded for investigation.In order to collect the relevant data from the respondents ,the mall intercept method was adopted and the respondents are chosen alternatively to ensure randomeness in the sample.The various retail shopping malls include Reliance shopping mall,Big Baaar shopping mall,Spencer's shopping mall and More shopping mall and Viashal shopping mall,Food Bazaar shopping malls The statistical methods used in the present study includes the percentages,chi-square methods, and also the factor analysis. The suitable charts , diagrams and tables are used to explain in precise manner

\section{DATA ANALYSIS AND INTERPRETATION}

1) Do you agree that the distance from home has no impact upon the purchase intention of store brands, if the free home delivery service is provided? 


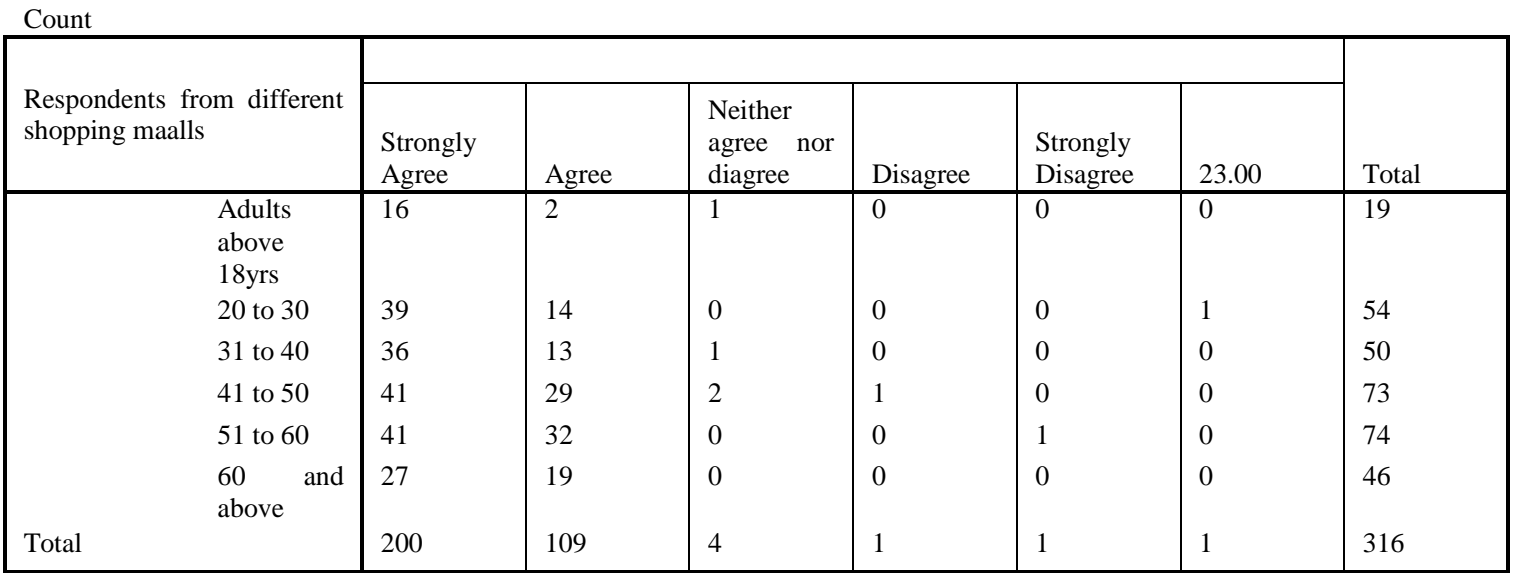

Chi-Square Tests

\begin{tabular}{|l|l|l|l|}
\hline & Value & Df & $\begin{array}{l}\text { Asymp. } \\
\text { Sig. } \\
\text { sided) }\end{array}$ \\
\hline $\begin{array}{l}\text { Pearson Chi- } \\
\text { Square }\end{array}$ & 29.777 & 25 & .233 \\
$\begin{array}{l}\text { Likelihood } \\
\text { Ratio } \\
\begin{array}{l}\text { Linear-by- } \\
\text { Linear } \\
\text { Association }\end{array}\end{array}$ & 29.574 & 25 & .241 \\
$\begin{array}{l}\text { N of Valid } \\
\text { Cases }\end{array}$ & 316 & 1 & .946 \\
\hline
\end{tabular}

Table no.1.1:The impact study of distance on purchase intentions of store brands, if free home delivery service is provided

\section{HYPOTHESIS:}

$\mathrm{H}_{0}$ :The distance from home has no impact up on the purchase intention of store brands, if the free home delivery service is provided .

$\mathrm{H}_{1}$ : The distance from home has impact up on the purchase intention of store brands, even if the free home delivery service is provided.

The $\chi^{2}$ calculated value is 29.77 which is less than $\chi^{2}$ table value(37.65), and hence the null hypothesis is accepted,and the alternative hypothesis is rejected at $\alpha=5 \%$ and $p=0.233$ which is more than $\alpha$ value.

2)Do you agree that the distance from home has no impact up on the purchase intention of store brands, if purchases are made on single slot once a month basis?

Crosstab

Count

\begin{tabular}{|c|l|l|l|l|l|l|}
\hline $\begin{array}{l}\text { Respondents from different } \\
\text { shopping maalls }\end{array}$ & $\begin{array}{l}\text { Strongly } \\
\text { Agree }\end{array}$ & Agree & $\begin{array}{l}\text { Neither } \\
\text { agree } \\
\text { nor } \\
\text { diagree }\end{array}$ & Disagree & $\begin{array}{l}\text { Strongly } \\
\text { Disagree }\end{array}$ & Total \\
\hline $\begin{array}{l}\text { Adults above } \\
18 \text { yrs }\end{array}$ & 13 & 5 & 0 & 0 & 1 & 19 \\
20 to 30 & 37 & 14 & 3 & 0 & 0 & 54 \\
31 to 40 & 32 & 9 & 7 & 1 & 1 & 50 \\
41 to 50 & 41 & 24 & 7 & 1 & 0 & 73 \\
51 to 60 & 46 & 26 & 1 & 1 & 0 & 74 \\
60 and above & 23 & 20 & 2 & 0 & 1 & 46 \\
Total & 192 & 98 & 20 & 3 & 3 & 316 \\
\hline
\end{tabular}




Chi-Square Tests
\begin{tabular}{|l|l|l|l|}
\hline & Value & df & $\begin{array}{l}\text { Asymp. Sig. } \\
\text { (2-sided) }\end{array}$ \\
\hline $\begin{array}{l}\text { Pearson } \\
\text { Chi-Square } \\
\text { Likelihood } \\
\text { Ratio }\end{array}$ & 27.291 & 20 & .127 \\
$\begin{array}{l}\text { Linear-by- } \\
\text { Linear } \\
\text { Association } \\
\text { N of Valid } \\
\text { Cases }\end{array}$ & 316 & 20 & .080 \\
\hline
\end{tabular}

Table no.1.2 The impact study of distance on purchase intentions of store brands, if purchases are made on single slot once a month basis

\section{HYPOTHESIS:}

$\mathrm{H}_{0}$ :The distance from home has no impact up on the purchase intention of store brands, if purchases are made on single slot once a month basis

$\mathrm{H}_{1}$ : The distance from home has impact up on the purchase intention of store brands, even if purchases are made on single slot once a month basis

The $\chi^{2}$ calculated value is 27.29 which is less than $\chi^{2}$ table value (31.41), and hence the null hypothesis is accepted, and the alternative hypothesis is rejected at $\alpha=5 \%$ and $p=0.127$ which is more than $\alpha$ value.

3).Do you agree that the heavy discount offers on non-regularly purchased items has no influence on purchase intention of regularly purchased food and grocery items if the same kind of discounts are not provided ?

Crosstab

Count

\begin{tabular}{|c|c|c|c|c|c|c|}
\hline $\begin{array}{l}\text { Respondents from different } \\
\text { shopping maalls }\end{array}$ & $\begin{array}{l}\text { Strongly } \\
\text { Agree }\end{array}$ & Agree & $\begin{array}{l}\text { Neither } \\
\text { agree nor } \\
\text { diagree }\end{array}$ & Disagree & $\begin{array}{l}\text { Strongly } \\
\text { Disagree }\end{array}$ & Total \\
\hline $\begin{array}{l}\text { Adults } \\
\text { above } \\
18 \text { yrs } \\
20 \text { to } 30 \\
31 \text { to } 40 \\
41 \text { to } 50 \\
51 \text { to } 60 \\
60 \quad \text { and } \\
\text { above }\end{array}$ & $\begin{array}{l}32 \\
33 \\
43 \\
52 \\
29 \\
199\end{array}$ & $\begin{array}{l}14 \\
13 \\
18 \\
17 \\
12 \\
80\end{array}$ & $\begin{array}{l}3 \\
4 \\
3 \\
1 \\
1 \\
13\end{array}$ & $\begin{array}{l}2 \\
0 \\
7 \\
4 \\
0\end{array}$ & $\begin{array}{l}3 \\
0 \\
2 \\
0 \\
4 \\
9\end{array}$ & $\begin{array}{l}54 \\
50 \\
73 \\
74 \\
46 \\
316\end{array}$ \\
\hline
\end{tabular}

\begin{tabular}{|c|c|c|c|}
\hline \multicolumn{4}{|c|}{ Chi-Square Tests } \\
\hline & Value & Df & $\begin{array}{l}\text { Asymp. } \\
\text { Sig. } \\
\text { sided) }\end{array}$ \\
\hline $\begin{array}{l}\text { Pearson Chi- } \\
\text { Square }\end{array}$ & 26.469 & 20 & .151 \\
\hline $\begin{array}{l}\text { Likelihood } \\
\text { Ratio }\end{array}$ & 31.779 & 20 & .046 \\
\hline $\begin{array}{l}\text { Linear-by- } \\
\text { Linear } \\
\text { Association }\end{array}$ & .551 & 1 & .458 \\
\hline $\begin{array}{l}\mathrm{N} \text { of Valid } \\
\text { Cases }\end{array}$ & 316 & & \\
\hline
\end{tabular}

Table no.1.3 The impact study of discount types on purchase intentions of store brands in food and grocery

\section{HYPOTHESIS:}

$\mathrm{H}_{0}$ : The heavy discount offers on non-regularly purchased items has no influence on purchase intention of regularly purchased food and grocery items if the same kind of discounts are not provided

$\mathrm{H}_{1}$ : The heavy discount offers on non-regularly purchased items has influence on purchase intention of regularly purchased food and grocery items if the same kind of discounts are not provided 
The $\chi 2$ calculated value is 26.46 which is less than $\chi^{2}$ table value(31.41), and hence the null hypothesis is accepted, and the alternative hypothesis is rejected at $\alpha=5 \%$ and $p=0.151$ which is more than $\alpha$ value.

4)Do you agree that the visiting frequency to the store has no influence up on the store brand loyalty if total purchases are made in single slot and on once a month basis?

\begin{tabular}{|l|l|l|l|l|l|l|}
\hline Count \\
\begin{tabular}{|c|l|l|l|l|} 
Respondents from different \\
shopping maalls
\end{tabular} & $\begin{array}{l}\text { Strongly } \\
\text { Agree }\end{array}$ & Agree & $\begin{array}{l}\text { Neither } \\
\text { agree nor } \\
\text { diagree }\end{array}$ & Disagree & $\begin{array}{l}\text { Strongly } \\
\text { Disagree }\end{array}$ & Total \\
\hline \multirow{2}{*}{$\begin{array}{l}\text { Adults } \\
\text { above }\end{array}$} & 12 & 4 & 1 & 2 & 0 & 19 \\
18 yrs & & & & & & \\
20 to 30 & 31 & 10 & 7 & 6 & 0 & 54 \\
31 to 40 & 22 & 15 & 10 & 2 & 1 & 50 \\
41 to 50 & 37 & 21 & 5 & 10 & 0 & 73 \\
51 to 60 & 35 & 17 & 7 & 12 & 3 & 74 \\
60 and & 25 & 12 & 2 & 7 & 0 & 46 \\
above & & 79 & 32 & 39 & 4 & 316 \\
\hline
\end{tabular}

Chi-Square Tests
\begin{tabular}{|l|l|l|l|}
\hline & Value & df & $\begin{array}{l}\text { Asymp. } \\
\text { Sig. (2- } \\
\text { sided) }\end{array}$ \\
\hline $\begin{array}{l}\text { Pearson Chi- } \\
\text { Square } \\
\begin{array}{l}\text { Likelihood } \\
\text { Ratio } \\
\text { Linear-by- }\end{array}\end{array}$ & 23.288 & 20 & .275 \\
$\begin{array}{l}\text { Linear } \\
\text { Association }\end{array}$ & 1.141 & 1 & .223 \\
$\begin{array}{l}\text { of Valid } \\
\text { Cases }\end{array}$ & 316 & & .285 \\
\hline
\end{tabular}

Table no.1.4: The impact study of visiting frequency to the store on store brand loyalty if one time bulk purchases are made

\section{HYPOTHESIS:}

$\mathrm{H}_{0}$ : The visiting frequency to the store has no influence up on the store brand loyalty if total purchases are made in single slot and on once a month basis

$\mathrm{H}_{1}$ : The visiting frequency to the store has no influence up on the store brand loyalty if total purchases are made in single slot and on once a month basis

The $\chi 2$ calculated value is 23.28 which is less than $\chi^{2}$ table value (31.41), and hence the null hypothesis is accepted, and the alternative hypothesis is rejected at $\alpha=5 \%$ and $p=0.275$ which is more than $\alpha$ value.

5)Do you agree that the regularly weekly based discounts and promotional offers have no impact up on the purchase intention of store brands if total purchases are made on single slot, once a month basis? 


\begin{tabular}{|c|c|c|c|c|c|c|}
\hline $\begin{array}{l}\text { Respondents from } \\
\text { different shopping maalls }\end{array}$ & $\begin{array}{l}\text { Strongly } \\
\text { Agree }\end{array}$ & Agree & $\begin{array}{l}\text { Neither } \\
\text { agree nor } \\
\text { diagree }\end{array}$ & Disagree & $\begin{array}{l}\text { Strongly } \\
\text { Disagree }\end{array}$ & Total \\
\hline $\begin{array}{l}\text { Adults } \\
\text { above } \\
18 \mathrm{yrs}\end{array}$ & 4 & 6 & 5 & 3 & 1 & 19 \\
\hline 20 to 30 & 24 & 9 & 12 & 4 & 5 & 54 \\
\hline 31 to 40 & 23 & 7 & 11 & 4 & 5 & 50 \\
\hline 41 to 50 & 19 & 18 & 12 & 12 & 12 & 73 \\
\hline 51 to 60 & 20 & 24 & 11 & 12 & 7 & 74 \\
\hline $\begin{array}{l}60 \text { and } \\
\text { above }\end{array}$ & 14 & 19 & 7 & 2 & 4 & 46 \\
\hline Total & 104 & 83 & 58 & 37 & 34 & 316 \\
\hline
\end{tabular}

\begin{tabular}{|c|c|c|c|}
\hline & Value & Df & $\begin{array}{l}\text { Asymp. } \\
\text { Sig. } \\
\text { sided) }\end{array}$ \\
\hline $\begin{array}{l}\text { Pearson } \\
\text { Chi-Square }\end{array}$ & 29.599 & 20 & .077 \\
\hline $\begin{array}{l}\text { Likelihood } \\
\text { Ratio }\end{array}$ & 29.875 & 20 & .072 \\
\hline $\begin{array}{l}\text { Linear-by- } \\
\text { Linear } \\
\text { Association } \\
\mathrm{N} \text { of Valid } \\
\text { Cases }\end{array}$ & 316 & 1 & .750 \\
\hline
\end{tabular}

Table no.1.5:The impact study of discount offers on store brands if one time bulk purchases are made

\section{HYPOTHESIS:}

$\mathrm{H}_{0}$ : The regularly weekly based discounts and promotional offers have no impact up on the purchase intention of store brands if total purchases are made on single slot, once a month basis

$\mathrm{H}_{1}$ : The regularly weekly based discounts and promotional offers have impact up on the purchase intention of store brands if total purchases are made on single slot, once a month basis

The $\chi 2$ calculated value is 29.59 which is less than $\chi^{2}$ table value (31.41), and hence the null hypothesis is accepted, and the alternative hypothesis is rejected at $\alpha=5 \%$ and $p=0.07$ which is more than $\alpha$ value.

\section{Discussion And Implications}

The present research study reveals that the shoppers have changed their opinions regarding distance,time and physical efforts to reach the store etc., and they mainly focus on the responsive attitude of the retailers and their in-time decisions to help the consumers and grasp the feelings,opininoins, suggestions and ideas of the consumers in a constructive manner.The study forms the foundation of key constructs which affect the strategic planning and implementation processes.It is essential that the psychological barriers that inhibit the purchase intentions of the buyers, are removed from the mindsets of the shoppers. The findings help the retailers to align their strategies with the changing lifestyles of the modern shoppers of the retailing world.These dimensions have far reaching implications for retailers in understanding and evaluating the shopper's behavior before and after the actual purchasing process.Today's shopper are in dire need of retailer's help in selecting,purchasingand delivering the required food and grocery items as they find themselves completely exhausted after office hours. The retailers of the present age have multiple responsibilities and functions to be closer and more helpful to customers, other than just displaying and selling items at the store.There is a need of assuming a family well wisher role on the shoulders of the select retailer. The customer relationship management is very crucial in evaluating the retail consumers. 


\section{Conclusion}

The findings of the present study contributes to the international and national retailers for the better understanding of the changing lifestyles and perceptions of Indian consumers. The study reveals from the findings that the variables have no impact on the customer purchase intentions if the conditional attributes are analysed and addressed appropriately in their retail strategies. The first factor is that the the distance from home has no impact upon the purchase intention of store brands, if the free home delivery service is provided to the select profitable shoppers.The invisible pressures on the the customer-employee s are lifted up by the retailer and the retailer makes the customer's job easy.The second factor is that the the distance from home has no impact up on the purchase intention of store brands, if purchases are made on single slot once a month basis.And the third factor is that the heavy discount offers on non-regularly purchased items has no influence on purchase intention of regularly purchased food and grocery items if the same kind of discounts are not provided.The customers feel disappointed when they find that their regularly purchased food items are soild at no or little discounts. So , the retailer must focus on this aspect and motivate the buyers to buy more by offering a good and handsome discount.

The fourth factor is that the visiting frequency to the store has no influence up on the store brand loyalty if total purchases are made in single slot and on once a month basis. This is mainly due to the fact that the customers expect, in future, fluctuations in prices in food and products that are daily essential.The retailer has to focus on this aspect and give a rational discouts to motivate them to buy more quantity of items selected by the consumer because consumer buys on a monthly single slot basis.It also reduces time pressures on visits in a month The retailer's duty is that the customer remembersto re-visit even after a month keeping in view of the benefits sought in the select store.The last but not the least factor is that the regularly and weekly based discounts and promotional offers have no impact up on the purchase intention of store brands if total purchases are made on single slot, once a month basis.It is clear from the findings that the distance,time are no more issues if the retailer tactfully addresses the issues by making effective consumer motivating strategies. These steps will assure the retailers of upholding loyalty and customer satisfaction.

\section{LIMITATIONS OF TH STUDY:}

The present study is limited to the twin cities of Hyderabad and the sample sie is 316.respondents.This research being part of the main research,is presently confined to the select cities and it will be extended to other cities in future to represent a substantial number of subjects to represent the whole population.The present study will be useful for longitudinal studies. The study can be extended to super markets,kirana and mom and me storesas well. And it is more useful in studying the purchase intentions of shoppers of other categories of private label brands .

\section{References:}

[1] AllawadiK,Keller K(2004).Understanding retail branding:conceptual insights and research priorities,J. retailing80:331-342

[2] Huang G,Alex SL,Tsang,Nan hou,JAF(2006).'Impact of situational factors on buying decisions in shopping malls",Europian Journal of Marketing,40(1),pp17-43.

[3] Mitchel VW(1998)."A Role of consumer risk perceptions in grocery retailing",British Food Journal

[4] Outi uusitalo(2001)."consumer perceptions Of grocery retail formats and brands",Int.Journal of Retail and Distribution management29(5);214-225.

[5] Planet retail. (2008).Private Label Trends World Wide.Presentation delivered in Mumbai,India by Paul Martin,Global Sales Manager

[6] Richardson P,Jain A, Dick A(1996).The influence of store aestheticson evaluation of private label brands,J.Product Brand manage.5(1):19-28

[7] Rusch R(2002).Private labels:Does branding matter?.Brand channel,New York;http://www.brandchannel.comfeatures_effect.asp?pf_id=94.Dated 6 May.

[8] Sinha Piyush kumar(2003)"Shopping orientation in the evolving Indian Market",Vikalpa,28(2),pp13-22

[9] Sridhar.G(2007.,"consumer involvement in product choice:role of perceived risk",Decision,34(2),pp51-66

[10] Tirthala Naga Sai Kumar and M. Ravinder Reddy (2013)," The Loyalty Determinant Attributes Of Store Brands In Food And Grocery In Indian Retailing-An Empirical Study In Twin CitiesOf Hyderabad”, Journal of Humanities And Social Science(IOSRJHSS), volume17.Issue3 (Nov-Dec.2013)pages22-28. 